\title{
KOMPARASI DESAIN TEBAL PERKERASAN KAKU MENGGUNAKAN MANUAL DESAIN PERKERASAN JALAN 2017 DAN METODE AASHTO 1993
}

\section{THE COMPARISON DESIGN OF THE RIGID PAVEMENT USING THE METHOD OF BINA MARGA 2017 AND AASHTO 1993 METHOD}

\author{
Muhammad Djaya Bakri \\ Program Studi Teknik Sipil, Fakultas Teknik Universitas Borneo Tarakan \\ Email: jayabakri@gmail.com
}

\begin{abstract}
ABSTRAK
Pada tahun 2019, Universitas Borneo Tarakan merencanakan membangun jalan lingkungan baru dalam kawasan kampus. Mengingat keterbatasan kemampuan anggaran dalam pemeliharaan sarana dan prasarana pasca kontruksi, maka jalan lingkungan baru ini di desain berupa kontruksi perkerasan kaku pelat beton, dengan mempertimbangkan kemudahan pelaksanaan, umur keawetan kontruksi lebih lama dan biaya pemeliharaan yang relatif rendah sepanjang umur rencana (discounted lifecycle cost). Digunakan dua metode desain, yaitu metode MDPJ 2017 dan metode AASHTO 1993, sebagai instrumen komparasi untuk mendapatkan tebal pelat beton yang ekonomis berdasarkan beban lalulintas yang direncanakan. Studi ini memberikan dimensi pelat beton perkerasan hasil analisis dengan metode MDPJ 2017 setebal $170 \mathrm{~mm}$, dan hasil analisis dengan metode AASHTO 1993 setebal $200 \mathrm{~mm}$. Perbedaan hasil pada kedua metode relatif kecil (1,4\%), meskipun terdapat perbedaan beberapa parameter, tetapi tidak berpengaruh secara signifikan.
\end{abstract}

Kata Kunci: perkerasan kaku, MDPJ 2017, metode AASHTO 1993

\begin{abstract}
Universitas Borneo Tarakan in 2019 to plans to build a new local road within the campus area. Given the limited capacity of the budget in maintaining post-construction facilities and infrastructure, this new environmental road is designed in the form of a concrete slab rigid pavement construction, taking into account the ease of implementation, longer construction life span and relatively low maintenance costs throughout the planned life (discounted lifecycle cost). Two design methods were used, namely the 2017 MDPJ method and the 1993 AASHTO method, as a comparative instrument to obtain an economical concrete slab thickness based on the planned traffic load. This study provides the dimensions of the pavement concrete slab analyzed by the MDPJ 2017 method with a thickness of $200 \mathrm{~mm}$, and the results of the analysis using the AASHTO 1993 method with a thickness of $200 \mathrm{~mm}$. There is an 11\% difference between the two methods, this is due to some differences in the design parameters.
\end{abstract}

Keywords: rigid pavement, Bina Marga 2017 Methode, ASSHTO 1993 Methode

\section{PENDAHULUAN}

Universitas Borneo Tarakan pada Tahun 2019, merencanakan membangun jalan lingkungan baru dalam kawasan kampus sebagai upaya untuk meningkatkan konektivitas antar zonasi dan meningkatkan kontrol keamanan kawasan kampus, terutama antara kawasan yang sudah berkembang dengan kawasan baru yang dikembangkan dalam kampus, sebagaimana ditampilkan pada Gambar 1 
JURNAL BORNEO SAINTEK

Volume 3, Nomor 2, Oktober 2020

e-ISSN 2599-3313

P-ISSN 2615-434X

(Bakri, 2020). Dalam pembangunan jalan, baik jalan baru maupun peningkatan kualitas jalan lama selalu diawali dengan kegiatan desain teknis konstruksi jalan beserta utilitasnya (Hendarsin, 2000). Setidaknya ada empat aspek yang menjadi produk perencanaan jalan, yaitu perencanaan geometrik, perkerasan, utilitas dan anggaran biayanya. Salahsatu aspek yang menarik dianalisis adalah dalam hal desain perkerasan jalan (Nawir \& Mansur, 2017).

Studi (Bakri, 2020) sebelumnya pada trase jalan lingkungan baru dalam kawasan kampus Universitas Borneo
Available online at www.jurnal.borneo.ac.id Halaman 47-60

Tarakan, menganalisis perkerasan jalan dengan jenis kontruksi perkerasan lentur (flexible pavement). Dalam studi ini, kembali dianalisis tebal perkerasannya dengan tipe perkerasan kaku (rigid pavement). Desain perkerasan kaku dapat menggunakan bermacam metode yang biasa digunakan dalam desain perkerasan jalan di Indonesia, diantaranya adalah menggunakan metode Bina Marga 2017 dan metode AASHTO 1993. Kedua metode tersebut digunakan dalam studi ini untuk mengetahui hasil desain yang sesuai dengan kondisi geoteknik lokasi rencana pembangunan jalannya.

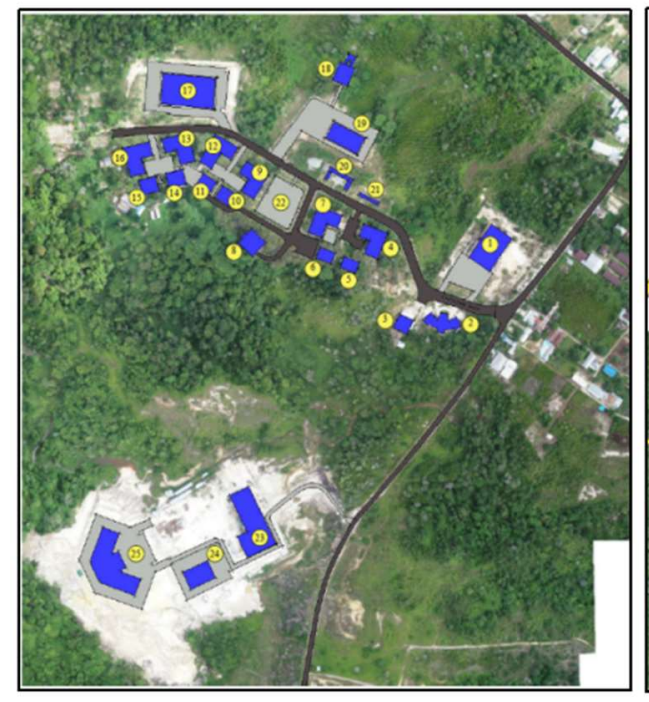

(a). Kondisi Eksisting Kawasan
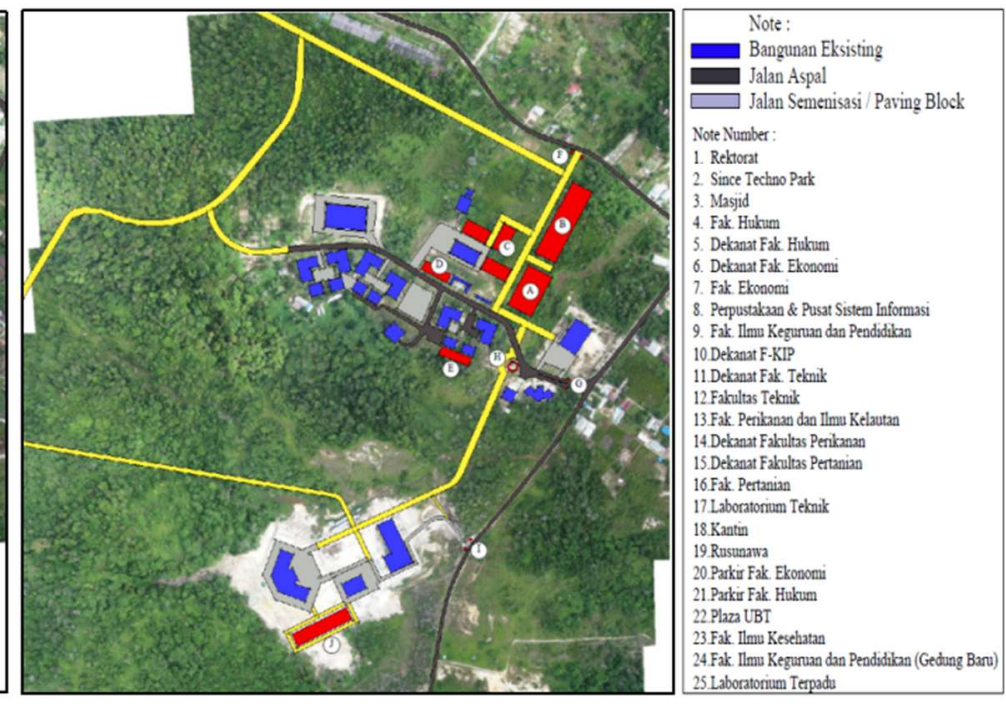

(b). Rencana Jalan Baru Kawasan

\section{Gambar 1. Rencana Jalan Lingkungan Baru Dalam Kawasan Kampus UBT (Sumber: Bakri, 2020)}

\section{METODE PENELITIAN}

\section{a. Metode Bina Marga 2017}

Manual Desain Perkerasan Jalan (Revisi 2017) atau dikenal dengan Metode Bina Marga 2017, diterbitkan oleh Direktorat Jenderal Bina Marga Kementerian Pekerjaan Umum dan Perumahan Rakyat (Direktorat Jenderal Bina Marga, 2017). Pada metode ini, terdapat parameter desain yang digunakan sebagaimana diuraikan dibawah ini.

1. Umur rencana (UR)

Umur rencana perkerasan jalan baru untuk jenis perkerasan kaku disyaratkan selama 40 tahun (Direktorat Jenderal Bina Marga, 2017).

2. Lalu lintas

Beban lalu lintas dinyatakan dalam julah kelompok sumbu niaga, sesuai dengan konfigurasi sumbu pada lajur rencana selama umur rencana. Konfigurasi sumbu untuk analisis dibagi dalam 4 tipe, yaitu: sumbu tunggal roda tunggal (STRT), sumbu tunggal roda ganda (STRG), sumbu tandem roda ganda (STrRG), dan sumbu tridem roda ganda (STrRG)(Ardiansyah \& Sudibyo, 
JURNAL BORNEO SAINTEK

Volume 3, Nomor 2, Oktober 2020

e-ISSN 2599-3313

P-ISSN 2615-434X
Available online at www.jurnal.borneo.ac.id Halaman 47-60
2020). Jenis kendaraan dikelompok menjadi Sembilan tipe, yaitu: $5 B, 6 A$, 6B, 7A1, 7A2, 7C1, 7C2A, 7C2B, dan 7C3 (Departemen Permukiman dan Prasarana Wilayah, 2004).

Dalam analisis lalulintas terdapat beberapa pameter yang dianalisis, sebagai berikut:

(a). Volume lalu lintas, berupa beban gandar kendaraan niaga yang dinyatakan dalam beban sumbu gandar (Vinna et al., 2019).

(b). Faktor pertumbuhan lalu lintas (i), berdasarkan data series pertumbuhan lalu lintas pada wilayah studi, jika tidak tersedia, maka dapat digunakan nilai (i) seperti disajikan pada Tabel 1.

Tabel 1. Faktor Laju Pertumbuhan Lalu Lintas (i) (\%) (2015-2035)

\begin{tabular}{lcccc} 
& Jawa & Sumatera & Kalimantan & Rerata Indonesia \\
\hline Arteri dan perkotaan & 4,80 & 4,83 & 5,14 & 4,75 \\
Kolektor rural & 3,50 & 3,50 & 3,50 & 3,50 \\
Jalan desa & 1,00 & 1,00 & 1,00 & 1,00 \\
\hline
\end{tabular}

Sumber: Direktorat Jenderal Bina Marga (2017)

Pertumbuhan lalu lintas selama umur rencana dihitung dengan factor pertumbuhan kumulatif (cumulative growth factor) sebagai berikut (Direktorat Jenderal Bina Marga, 2017):

$$
R=\frac{(1+0,01 i)^{U R}-1}{0,01 i}
$$

Dengan:

$\mathrm{R}=$ faktor pengali pertumbuhan lalu lintas kumulatif;

$\mathrm{i}$ = laju pertumbuhan lalu lintas tahunan (\%), dan

$\mathrm{UR}=$ umur rencana (tahun). (c). Lalu lintas pada lajur rencana, beban lalu lintas dinyatakan dalam kumulatif beban gandar standar (ESA) dengan memperhitungan faktor distribusi arah (DD) dan faktor distribusi lajur kendaraan niaga (DL). Faktor distribusi arah (DD) umumnya diambil nilai 0,5 untuk jalan dua arah, kecuali pada lokasi dengan jumlah kendaraan niaga cenderung lebih tinggi pada satu arah tertentu. Faktor distribusi lajur yang digunakan dengan mengacu pada jumlah lajur setiap arah seperti disajikan pada Tabel 2 .

\section{Tabel 2. Faktor Distribusi Lajur (DL)}

\section{Jumlah Lajur Setiap Arah}

Kendaraan Niaga Per Lajur Desain (\% Terhadap Populasi Kendaraan Niaga)

$\begin{array}{lc}1 & 100 \\ 2 & 80 \\ 3 & 60 \\ 4 & 50\end{array}$

Sumber: Direktorat Jenderal Bina Marga (2017)

(d). Faktor Ekivalen Beban (Vehicle Damage Factor), merupakan faktor yang menyatakan perbandingan tingkat kerusakan yang disebabkan oleh satu lintasan kendaraan tertentu terhadap kerusakan yang diakibatkan oleh suatu lintasan beban sumbu standar. Beban lalu lintas ini dikonversi ke beban standar menggunakan VDF (Isnaini et al., 2019). Beban lalu lintas desain didasarkan pada distribusi kelompok sumbu kendaraan niaga (Departemen Permukiman dan Prasarana Wilayah, 2003).

(e). Beban Standar Kumulatif atau Cumulative Equivalent Single Axle Load (CESAL), merupakan jumlah kumulatif beban sumbu lalu lintas desain pada lajur rencana selama umur rencana, yang dihitung dengan persamaan sebagai berikut 
(Direktorat Jenderal Bina Marga, 2017):

$$
E S A_{T H-1}=\left(\sum L H R_{J K} \times V D F_{J K}\right) \times 365 \times D D \times D L \times R
$$

Volume sumbu kendaraan niaga $=\Sigma$ (Jumlah kelompok sumbu per kendaraan $\mathrm{x}$ LHR $\times$ DD $\times$ DL $\times R$ )

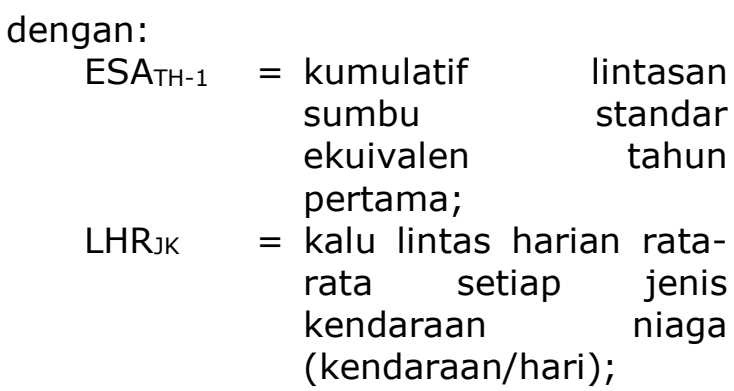

\section{Desain Perkerasan Kaku}

Departemen Permukiman dan Prasarana Wilayah (2003) memberikan prosedur desain perkerasan kaku didasarkan atas dua model kerusakan, yaitu: (1) retak fatik (lelah) tarik lentur pada pelat, dan (2) erosi pada pondasi bawah atau tanah dasar akibat lendutan. Analisis fatik dan erosi dianalisis dengan menghitung jumlah total fatik dengan menjumlahkan persentase fatik dari setiap jenis beban roda, kemudian dihitung jumlah total kerusakan akibat fatik dan jumlah total kerusakan akibat erosi untuk seluruh jenis kelompok sumbu untuk memperoleh tebal perkerasan desain yang didasarkan kerusakan akibat fatik dan atau erosi $\leq$ $100 \%$.

\section{b. Metode AASHTO 1993}

Metode AASHTO 1993 merupakan metode empirik yang dikembangkan oleh

$\begin{aligned} \text { VDFJK }= & \text { kaktor ekuivalen beban } \\ & \text { setiap jenis kendaraan } \\ & \text { niaga; } \\ = & \text { faktor distribusi arah; } \\ \mathrm{DD}= & \text { faktor distribusi lajur, } \\ \mathrm{DL}= & \text { dan } \\ \mathrm{R} & \text { faktor pengali } \\ & \text { pertumbuhan lalu lintas } \\ & \text { kumulatif. }\end{aligned}$

American Association of State Highway and Transportation Officials (AASHTO), merupakan penyempurnaan dari metode AASHTO 1986. Prinsip perancangan metode AASHTO 1993 berdasarkan kemampuan perkerasan melayani beban lalulintas selama umur rencana, dimana untuk perkerasan baru umumnya ditetapkan umur rencana 20 tahun (AASHTO, 1993).

Parameter desain perkerasan jalan yang digunakan pada metode ini, diuraikan berikut ini.

1. Lalu lintas.

Analisis lalu lintas yang dilakukan membutuhkan data jenis kendaraan, LHR, pertumbuhan lalu lintas tahunan (\%), VDF, DD, DL, dan ESAL selama umur rencana. Nilai ESAL dihitung dengan persamaan 4 (Isnaini et al., 2019):

$$
W_{18}=\sum_{N 1}^{N n} L H R_{j} \times V D F_{j} \times D_{D} \times D_{L} \times 365
$$

dengan:

$\begin{aligned} \mathrm{W}_{18}= & \text { traffic design pada lajur lalu } \\ & \text { lintas, Equivalent Single Axle } \\ & \text { Load }(E S A L) ;\end{aligned}$
$\mathrm{LHR}_{\mathrm{j}}=$ jumlah lalu lintas harian rata-rata 2 arah untuk jenis kendaraan $\mathrm{j}$;

$\mathrm{VDF}_{\mathrm{j}}=$ vehicle damage factor untuk jenis kendaraan $\mathrm{j}$; 
JURNAL BORNEO SAINTEK

Volume 3, Nomor 2, Oktober 2020

e-ISSN 2599-3313

P-ISSN 2615-434X
Available online at www.jurnal.borneo.ac.id Halaman 47-60

$$
\begin{aligned}
\mathrm{N} 1= & \text { lalu lintas pada tahun } \\
& \text { pertama jalan dibuka, dan } \\
\mathrm{Nn}= & \text { lalu lintas pada akhir tahun } \\
& \text { rencana. }
\end{aligned}
$$

2. Reliability

Realiabilitas didefinisikan sebagai kemungkinan tercapainya tingkat pelayanan pada level tertentu sepanjang umur rencana jalan yang di desain (Siegfried \& Rosyidi, 2007).

3. Serviceability

kemampuan pelayanan perkerasan, dinyatakan dalam Present Serviceability Index (PSI), yang merupakan selisih Initial Serviceability Index (Po) dengan Terminal Serviceability Index (Pt) (Dumin et al., 2017).

4. Modulus Reaksi Tanah Dasar

Berdasarkan nilai CBR, yang dikonversikan ke nilai Modulus Resilien $\left(M_{R}\right)$ dengan persamaan: $M_{R}$ $=1.500 \times \mathrm{CBR}$ (Putranto et al., 2016).

5. Modulus Elastisitas Beton ( $\mathrm{E}_{\mathrm{c}}$ )

Nilai Ec dihitung berdasarkan nilai kuat tekan beton silender $\left(f_{c}{ }^{\prime}\right)$, dimana nilai $f_{c}{ }^{\prime}$ ditetapkan sesuai spesifikasi pekerjaan (AASHTO, 1993).
6. Kuat Lentur Beton ( $\left.\mathrm{Sc}^{\prime}\right)$

Flexural strength (modulus of rupture) ditetapkan sesuai spesifikasi pekerjaan (Vinna et al., 2019).

7. Koefisien Drainase (Cd)

Nilai Cd merupakan faktor koreksi terhadap kinerja perkerasan akibat kondisi drainase yang kurang baik, dimana nilai $\mathrm{Cd}$ ini ditentukan oleh kualitas drainase dan persentase struktur perkerasan yang terdampak air sampai level mendekati jenuh air dalam satu tahun (Isnaini et al., 2019).

8. Koefisien Transfer Beban (J)

Nilai J merupakan koefisien yang memperhitungkan kemampuan perkerasan kaku mendistribusikan beban yang melintas diatas sambungan atau retakan (Setiawan, 2017).

9. Penentuan tebal Pelat (D)

penentuan tebal pelat perkerasan kaku dapat dilakukan dengan menggunakan nomogram AASHTO (Irawan et al., 2017), atau dengan analisis trial and error menggunakan persamaan 5 (Kurniawan et al., 2019).

$$
\begin{aligned}
& \log _{10} W_{18}=Z_{R} S_{o}+7,35 \log _{10}(D+1)-0,06+\frac{\log _{10}\left(\frac{\Delta P S I}{4,5-1,5}\right)}{1+\frac{1,62 \times 10^{7}}{(D+1)^{8,46}}}+ \\
& \left(4,22-0,32 P_{t}\right) \times \log _{10} \frac{S{ }_{C} C_{d} x\left[D^{0,75}-1,132\right]}{215,63 \times J \times\left[D^{0,75}-\frac{18,42}{\left(E_{C} / k\right)^{0,25}}\right]}
\end{aligned}
$$
dengan:
$\mathrm{W}_{18}=$ lalu lintas rancangan, Equivalent Single Axle Load (ESAL);
$Z_{R} \quad=$ simpangan baku normal;
So = standar deviasi keseluruhan, bernilai antara: 0,4-0,5;
$\Delta \mathrm{PSI}=$ selisih indeks pelayanan awal dengan indeks pelayanan akhir $(\triangle \mathrm{PSI}=$ $\mathrm{Po}_{\mathrm{O}} \mathrm{P}_{\mathrm{t}}$;

Po = index pelayanan awal, Initial serviceability (Po);

Pt = index pelayanan akhir, Initial serviceability (Po);

$\mathrm{S}^{\prime}{ }_{\mathrm{c}}=$ kuat tekan beton (psi);

$\mathrm{C}_{\mathrm{d}}=$ koefisien drainase;

J = koefisiean transfer beban;

$\mathrm{E}_{\mathrm{c}}=$ modulus elastisitas beton (psi), dan

$\mathrm{K}=$ modulus reaksi tanah dasar (psi). 
JURNAL BORNEO SAINTEK

Volume 3, Nomor 2, Oktober 2020

e-ISSN 2599-3313

P-ISSN 2615-434X

Menurut (Direktorat Jenderal Bina Marga, 2017), pemilihan jenis perkerasan tidak hanya berdasarkan volume lalu lintas, umur rencana dan kondisi pondasi jalan, tetapi juga mempertimbangkan faktor biaya terendah untuk pemeliharaan selama umur rencana dan kemudahan dalam pelaksanaan. Volume lalu lintas dalam kawasan kampus Universitas Borneo Tarakan setiap tahun mengalami peningkatan seiring dengan pertambahan jumlah penerimaan mahasiswa baru (Bakri, 2020), sehingga pada studi ini akan menggunakan desain perkerasan kaku dengan mempertimbangkan kemudahan pelaksanaan, umur keawetan kontruksi
Available online at www.jurnal.borneo.ac.id Halaman 47-60

lebih lama dan biaya pemeliharaan yang relatif rendah sepanjang umur rencana (discounted lifecycle cost).

Isnaini et al (2019) menyebutkan bahwa kekuatan perkerasan kaku sangat tergantung kekuatan pelat beton yang dinyatakan dalam nilai kuat tarik lentur (flextural strength) dengan umur beton 28 hari, sedangkan tebal perkerasan beton dapat ditentukan berdasarkan kelompok sumbu kendaraan beratnya.

Manual Desain Perkerasan Jalan 2017 (Direktorat Jenderal Bina Marga, 2017) memberikan pedoman untuk tebal pelat beton perkerasan kaku untuk beban lalu lintas rendah sebagaimana disajikan pada Tabel 3.

\section{Tabel 3. Standar Tebal Pelat Beton Perkerasan Kaku Dengan Beban Lalulintas}

\section{Berat}

\begin{tabular}{|c|c|c|c|c|c|}
\hline $\begin{array}{c}\text { Struktur } \\
\text { Perkerasan } \\
\end{array}$ & $\mathbf{R} \mathbf{1}$ & $\mathbf{R} \mathbf{2}$ & $\mathbf{R 3}$ & R4 & R5 \\
\hline \multicolumn{6}{|l|}{$\begin{array}{l}\text { Kelompok } \\
\text { sumbu }\end{array}$} \\
\hline $\begin{array}{l}\text { kendaraan berat } \\
\text { (overloaded) } \\
\left(10^{6}\right)\end{array}$ & $<4,3$ & $<8,6$ & $<25,8$ & $<43$ & $<86$ \\
\hline $\begin{array}{l}\text { Dowel dan bahu } \\
\text { beton }\end{array}$ & & & Ya & & \\
\hline \multicolumn{6}{|c|}{ Struktur Perkerasan (mm) } \\
\hline $\begin{array}{l}\text { Tebal pelat } \\
\text { beton }\end{array}$ & 265 & 275 & 285 & 295 & 305 \\
\hline $\begin{array}{l}\text { Lapis Pondasi } \\
\text { LMC }\end{array}$ & & & 100 & & \\
\hline $\begin{array}{l}\text { Lapis Drainase } \\
\text { (dapat mengalir } \\
\text { dengan baik) }\end{array}$ & & & 150 & & \\
\hline
\end{tabular}

Sumber: Direktorat Jenderal Bina Marga (2017)

\section{c. Alur Penelitian}

Alur penelitian digambarkan dalam bentuk flow chart untuk mempermudah sistematika penelitian seperti ditampilkan pada Gambar 2. Objek perancangan perkerasan jalan beton pada studi ini adalah Jalan Lingkungan Baru dalam kawasan kampus Universitas Borneo Tarakan, seperti ditunjukkan pada

Gambar 1 (b), dimana trase jalan rencana diberi warna kuning. Data yang dipergunakan berupa data Ialulintas, faktor laju pertumbuhan lalu lintas per tahun (i), data CBR tanah dasar bersumber dari Laporan Hasil Perencanaan Jalan Lingkungan Dalam Kawasan Kampus Universitas Borneo Tarakan Tahun 2019 (CV. Menara Konsultan, 2019). 


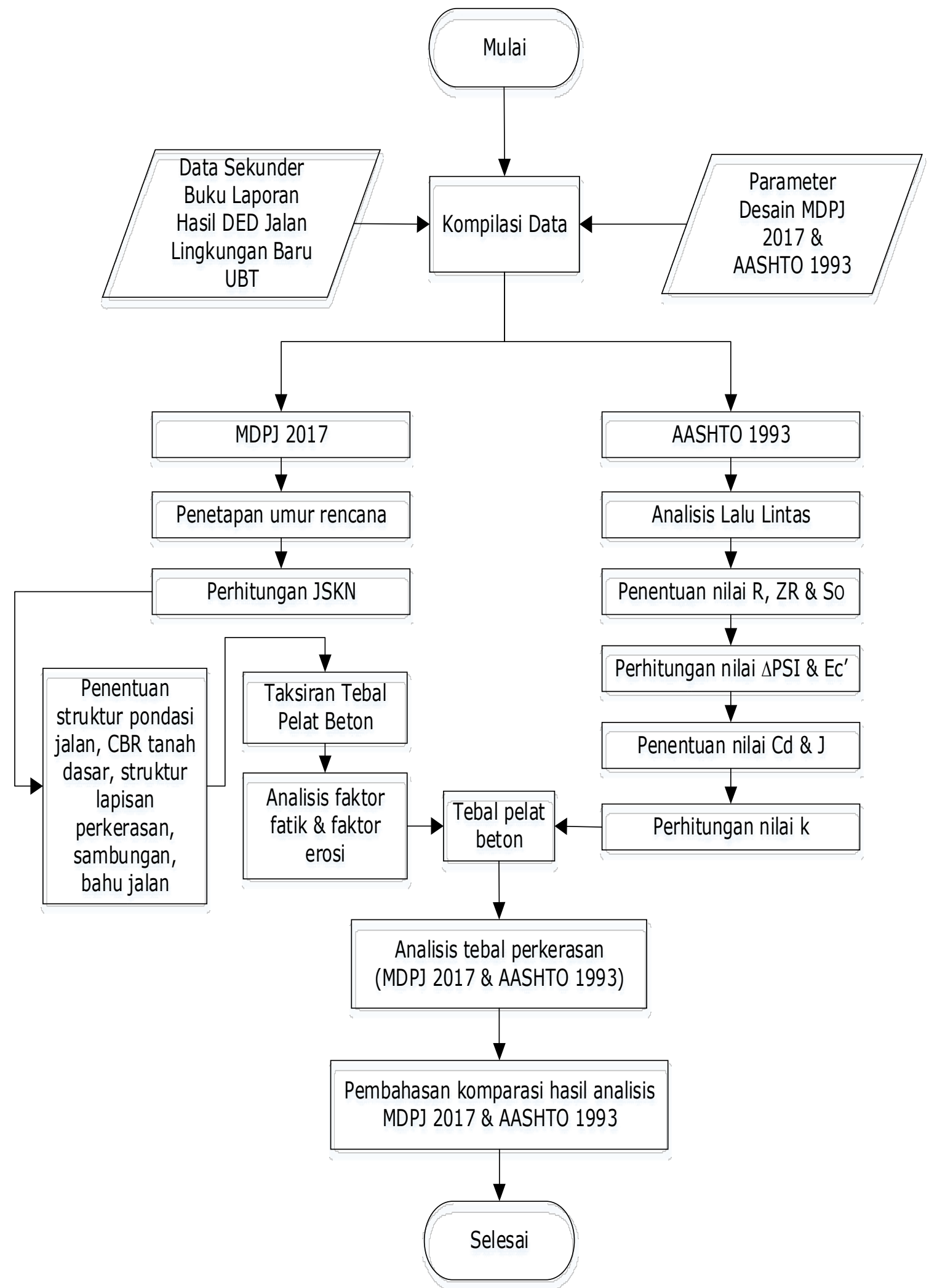

Gambar 2. Flow Chart Penelitian

Prosedur desain perkerasan kaku MDPJ 2017 meliputi penentuan umur rencana perkerasan, analisis volume kelompok sumbu kendaraan niaga (JSKN), penentuan struktur pondasi jalan, CBR tanah dasar, struktur lapisan 
JURNAL BORNEO SAINTEK

Volume 3, Nomor 2, Oktober 2020

e-ISSN 2599-3313

P-ISSN 2615-434X

perkerasan, taksiran tebal pelat, analisis faktor fatik dan erosi hingga mendapatkan tebal perkerasan rencana. Algoritma desain perkerasan kaku metode AASHTO 1993, diantaranya diperlukan penentuan umur rencana, analisis lalu lintas meliputi LHR, penentuan pertumbuhan lalu lintas, faktor distribusi arah, faktor distribusi lajur, hingga faktor VDF yang digunakan untuk menghitung traffic design. Parameter lainnya adalah simpangan baku normal $\left(Z_{R}\right)$, deviasi standar (So), kemampuan layan ( $\triangle \mathrm{PSI}$ ), modulus reaksi tanah dasar, modulus elastisitas beton, kuat tekan beton, koefisien drainase, serta koefisien transfer beban. Selanjutnya semua parameter dianalisis secara trial and error menggunakan Persamaan (5) hingga tebal pelat desain perkerasan jalan kaku.
Available online at www.jurnal.borneo.ac.id Halaman 47-60

\section{HASIL DAN PEMBAHASAN}

\section{a. Metode MDPJ 2017}

Langkah awal desain menggunakan metode MDPJ 2017, adalah analisis Jumlah Kelompok Sumbu Kendaraan Niaga (JSKN). Data lalulintas yang digunakan berdasarkan studi terdahulu (CV. Menara Konsultan, 2019). Fase kontruksi diasumsikan dimulai Tahun 2020 dan selama 2 tahun, dan jalan mulai dipergunakan pada Tahun 2022. Tingkat pertumbuhan lalulintas selama fase kontruksi diasumsikan sesuai Tabel 1 , sebesar $3,5 \%$ pertahun, dan selama umur rencana meningkat menjadi $5,5 \%$ pertahun (Bakri, 2020). Umur rencana ditetapkan selama 20 tahun. Selanjut dilaksanakan analisis LHR sebagaimana disajikan pada Tabel 4.

Tabel 4. Analisis LHR

\begin{tabular}{lccc}
\multicolumn{1}{c}{ Jenis Kendaraan } & LHR 2019 & LHR 2020 & LHR 2022 \\
\hline \multicolumn{1}{c}{$(\mathbf{1})$} & $\mathbf{( 2 )}$ & $\mathbf{( 3 )}$ & $\mathbf{( 4 )}$ \\
\hline Minibus (5a) & 284 & 294 & 315 \\
Micro truck (6.2) & 545 & 564 & 604 \\
Truck 2 sumbu-sedang (7.2) & 174 & 180 & 193 \\
\hline
\end{tabular}

Sumber: Analisis Data, 2020

Keterangan:

(3) $=(2) \times(1+3,5 \%)^{1}$;

(4) $=(3) \times(1+3,5 \%)^{2}$.

Dengan mempergunakan nilai LHR pada Tabel 4, dan nilai Faktor Ekivalen Beban (VDF) sesuai MPDJ 2017, dianalisis nilai
Cumulatative Equivalent Single Axle (CESA), hasilnya disajikan pada Tabel 5.

Tabel 5. Analisis CESA

\begin{tabular}{|c|c|c|c|}
\hline Jenis Kendaraan & VDF4 & $\begin{array}{l}\text { ESA4 } \\
(2020) \\
\end{array}$ & $\begin{array}{c}\text { ESA4 } \\
(2022-2042)\end{array}$ \\
\hline (1) & (2) & (3) & (4) \\
\hline Minibus (5a) & 0,3 & $16.093,22$ & $601.110,77$ \\
\hline Micro truck $(6.2)$ & 0,8 & $82.354,95$ & $3.076 .106,77$ \\
\hline Truck 2 sumbu-sedang (7.2) & 1,6 & $52.586,28$ & $1.964 .192,95$ \\
\hline Jumlah ESA4 & & $151.034,45$ & $5.641 .410,49$ \\
\hline CESA4 (22-42) & & \multicolumn{2}{|c|}{$5.792 .444,94$} \\
\hline
\end{tabular}

Sumber: Analisis Data, 2020

Keterangan:

(3) $=(2) \times 365 \times D D \times D L \times R_{(2020) \text {, }}$

dimana:

$\mathrm{DD}=0,5 ; \mathrm{DL}=1 ;$ 


$$
\begin{aligned}
& \left.\mathrm{R}_{(2020)}=\left[(1+0,01 \times 3,5)^{1}-1\right) /(0,01 \times 3,5)\right]=1 ; \\
& \left.\mathrm{R}_{(2022-2042)}=\left[(1+0,01 \times 5,5)^{20}-1\right) /(0,01 \times 5,5)\right]=34,87
\end{aligned}
$$

Nilai CESA4(2022-2042) diperoleh sebesar $5,792 \times 10^{6}$ ESA4 dalam 20 tahun, merujuk Tabel 4.6 MDPJ 2017 (Direktorat Jenderal Bina Marga, 2017), memenuhi syarat menggunakan perkerasan kaku.

Untuk menentukan tebal pelat beton perkerasan kaku, dilakukan analisis jumlah kelompok sumbu kendaraan niaga (JSKN), dengan menggunakan hasil analisis LHR pada Tabel 4. Hasil analisis jumlah kelompok sumbu kendaraan niaga (JSKN) disajikan pada Tabel 6.

Tabel 6. Analisis Jumlah Sumbu Kendaraan Niaga (JSKN)

\begin{tabular}{lcccc}
\hline $\begin{array}{c}\text { Jenis Kenda- } \\
\text { raan }\end{array}$ & $\begin{array}{c}\text { Jumlah } \\
\text { Kelompok } \\
\text { Sumbu Per } \\
\text { Kenda-raan }\end{array}$ & LHR 2022 & $\begin{array}{c}\text { Kelompok } \\
\text { Sumbu 2022 }\end{array}$ & $\begin{array}{c}\text { JSKN } \\
\text { 2022-2042 }\end{array}$ \\
\hline (1) & $\mathbf{( 2 )}$ & $\mathbf{( 3 )}$ & $\mathbf{( 4 )}$ & $\mathbf{( 5 )}$ \\
\hline Minibus (5a) & 2 & 315 & 630 & $4.007 .405,15$ \\
Micro truck (6.2) & 2 & 604 & 1.209 & $7.690 .266,93$ \\
Truck 2 sumbu- & 2 & 193 & 386 & $2.455 .241,18$ \\
sedang (7.2) & \multicolumn{2}{c}{ Jumlah Sumbu Kendaraan Niaga (JSKN) 2022-2042 } & $14.152 .913,26$ \\
\hline
\end{tabular}

Sumber: Analisis Data, 2020

Keterangan:

(4) = (2) $\times(3) ;(5)=(4) \times D D \times D L \times R_{20} \times 365$

Hasil analisis JSKN diperoleh nilai sebesar $14,15 \times 10^{6}$. Berdasarkan Tabel 1, nilai JSKN yang diperoleh berada pada rentang R2 dan R3, secara interpolasi diperoleh ketebalan pelat beton sebesar $278,43 \mathrm{~mm}$, selanjutnya dibulatkan menjadi $280 \mathrm{~mm}$, dengan menggunakan mutu beton kelas $\mathrm{K}-300$ dengan kuat tarik lentur $\left(\mathrm{f}_{\mathrm{cr}}\right)=4 \mathrm{MPa}$. Lapis pondasi direncanakan menggunakan beton kurus (Lean Mix Concrete, LMC) setebal 100 $\mathrm{mm}$ dan mutu beton $\mathrm{f}^{\prime} \mathrm{c} 10 \mathrm{MPa}$, serta lapis pondasi drainase agregat kelas $A$ setebal $150 \mathrm{~mm}$.

Nilai CBR lapangan rerata diperoleh sebesar 6\% (CV. Menara Konsultan, 2019), kemudian untuk menentukan nilai CBR tanah dasar efektif, dilakukan korelasi nilai CBR menggunakan grafik sesuai pedoman Perencanaan Perkerasan Jalan Beton Semen Pd T-14-2003 (Departemen Permukiman dan Prasarana Wilayah, 2003), diperoleh nilai sebesar $42 \%$.

Selanjutnya tebal pelat beton yang dipergunakan dalam desain, diperoleh dengan menganalisis kekuatan pelat beton taksiran fatik dan faktor erosi dihitung berdasarkan komposisi lalulintas selama umur rencana. Tebal pelat beton yang terpilih adalah tebal taksiran yang paling kecil mempunyai nilai total fatik dan atau total kerusakan erosi lebih kecil atau sama dengan $100 \%$. Analisis proporsi beban sumbu ditampilkan pada Tabel 7.

\section{Tabel 7. Analisis Proporsi Beban}

\begin{tabular}{cccccc}
$\begin{array}{c}\text { Jenis } \\
\text { Kendaraan }\end{array}$ & $\begin{array}{c}\text { Konfigurasi beban } \\
\text { sumbu (ton) }\end{array}$ & $\begin{array}{c}\text { Jml } \\
\text { sumb }\end{array}$ & STRT & STRG & STdRG \\
\cline { 2 - 5 } & &
\end{tabular}




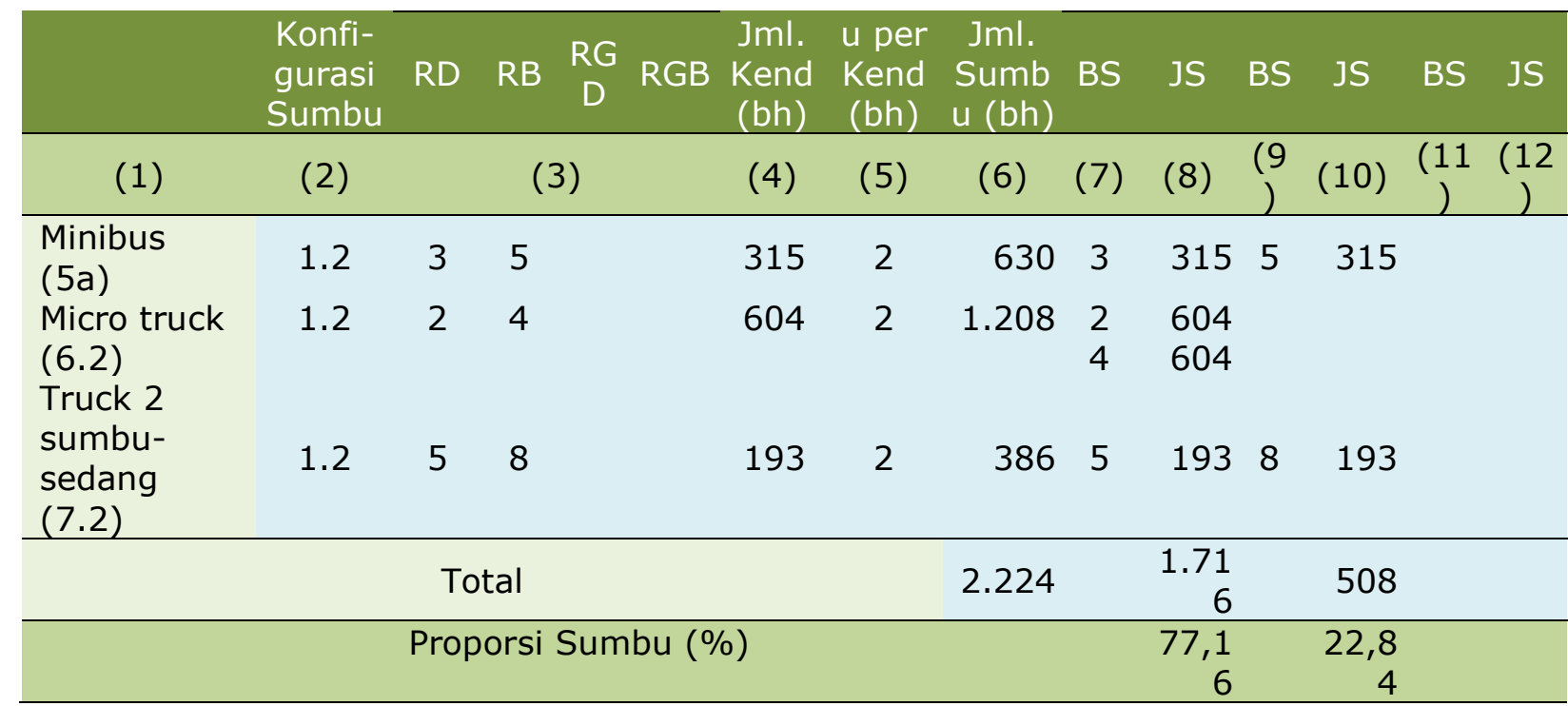

Sumber: Analisis Data, 2020

Keterangan:

$(6)=(4) \times(5) ; R D=$ roda depan; RB = roda belakang; RGD = roda gandeng depan; RGB = roda gandeng belakang; $B S=$ beban sumbu (ton); $\mathrm{JS}=$ jumlah sumbu (buah); STRT = sumbu tunggal roda tunggal; STRG = sumbu tunggal roda ganda; STdRG = sumbu tandem roda ganda.

Berikutnya dilaksanakan perhitungan repetisi beban sumbu rencana. Proses

analisis repetisi beban rencana ditampilkan pada Tabel 8.

\section{Tabel 8. Analisis Repetisi Beban}

\begin{tabular}{ccccccc}
\hline $\begin{array}{c}\text { Jenis } \\
\text { Sumbu }\end{array}$ & $\begin{array}{c}\text { Beban } \\
\text { Sumbu(ton) }\end{array}$ & $\begin{array}{c}\text { Jumlah } \\
\text { Sumbu }\end{array}$ & $\begin{array}{c}\text { Proporsi } \\
\text { Beban }\end{array}$ & $\begin{array}{c}\text { Proporsi } \\
\text { Sumbu }\end{array}$ & $\begin{array}{c}\text { Lalu lintas } \\
\text { Rencana }\end{array}$ & $\begin{array}{c}\text { Repetisi yang } \\
\text { terjadi }\end{array}$ \\
\hline (1) & $(2)$ & $(3)$ & $(4)$ & $(5)$ & $(6)$ & $(7)$ \\
\hline STRT & 5 & 193 & 0,11 & $77,16 \%$ & $14.152 .913,26$ & $1.201 .242,67$ \\
& 4 & 604 & 0,35 & $77,16 \%$ & $14.152 .913,26$ & $3.822 .135,75$ \\
& 3 & 315 & 0,19 & $77,16 \%$ & $14.152 .913,26$ & $2.074 .873,70$ \\
& 2 & 604 & 0,35 & $77,16 \%$ & $14.152 .913,26$ & $3.822 .135,75$ \\
\hline STRG & Total & 8 & 1.716 & & & \\
& & 193 & 0,38 & $22,84 \%$ & $14.152 .913,26$ & $1.228 .359,65$ \\
& 5 & 315 & 0,62 & $22,84 \%$ & $14.152 .913,26$ & $2.004 .165,74$ \\
\hline
\end{tabular}

Sumber: Analisis Data, 2020

Keterangan: $(4)=[(3) /$ Total tiap jenis sumbu $] ;(7)=(4) \times(5) \times(6)$

Hasil analisis repetisi beban seperti ditampilkan pada Tabel 8, dijadikan dasar dalam analisis fatik dan analisis erosi seperti ditampilkan pada Tabel 9. Perkerasan kaku ini didesain tanpa bahu beton tetapi menggunakan ruji/beton bertulang, dan tebal pelat beton taksiran sebsar $280 \mathrm{~mm}$. Untuk analisis beban rencana per roda, beban sumbu dikalikan dengan faktor keamanan beban ( $\left.F_{K B}\right)$ untuk jalan dengan volume kendaraan niaga rendah dengan nilai sebesar 1,0 (Departemen Permukiman dan Prasarana Wilayah, 2003).

Tabel 9. Analisis Fatik dan Analisis Erosi untuk Ketebalan Pelat Taksiran

\section{$280 \mathrm{~mm}$}




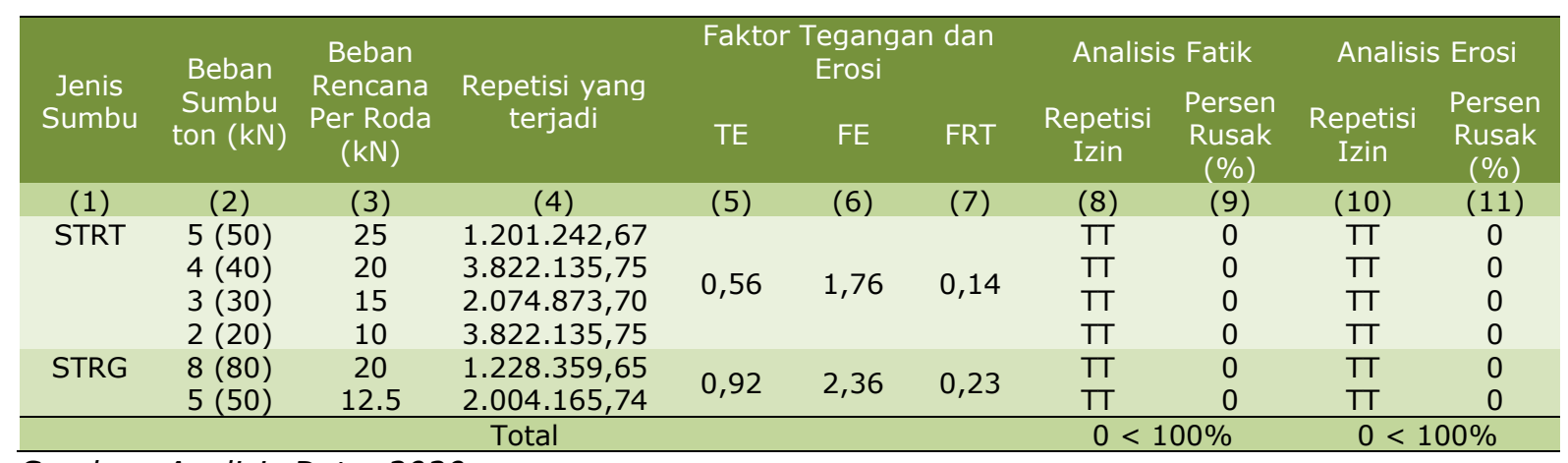

Sumber: Analisis Data, 2020

Keterangan: $(3)=(2) /$ Jumlah roda tiap sumbu; $(7)=(5) / f_{c r} ;(9)=(4) \times 100 \% /(8)$; nilai (5), (6), (8), dan (10) diperoleh dari Perencanaan Perkerasan Jalan Beton Semen (Pd T-14-2003)(Departemen Permukiman dan Prasarana Wilayah, 2003); TE = tegangan ekivalen; FE = faktor erosi; FRT = faktor rasio tegangan; $\Pi \mathrm{T}=$ tidak terhingga

Hasil analisis fatik dan analisis erosi untuk ketebalan taksiran sebesar 280 $\mathrm{mm}$, menunjukkan ketebalan taksiran tersebut sangat aman untuk menampung beban lalulintas rencana. Untuk mendapatkan tebal pelat beton ekonomis, dilakukan lagi analisis dengan ketebalan taksiran $170 \mathrm{~mm}$, seperti ditampilkan pada Tabel 10.

Tabel 10. Analisis Fatik dan Analisis Erosi untuk Ketebalan Pelat Taksiran

\section{$170 \mathrm{~mm}$}

\begin{tabular}{|c|c|c|c|c|c|c|c|c|c|c|}
\hline \multirow[b]{2}{*}{$\begin{array}{l}\text { Jenis } \\
\text { Sumbu }\end{array}$} & \multirow[b]{2}{*}{$\begin{array}{c}\text { Beban } \\
\text { Sumbu } \\
\text { ton }(k N)\end{array}$} & \multirow{2}{*}{$\begin{array}{c}\text { Beban } \\
\text { Rencana } \\
\text { Per Roda } \\
(\mathrm{kN})\end{array}$} & \multirow[b]{2}{*}{$\begin{array}{l}\text { Repetisi yang } \\
\text { terjadi }\end{array}$} & \multicolumn{3}{|c|}{$\begin{array}{c}\text { Faktor Tegangan dan } \\
\text { Erosi }\end{array}$} & \multicolumn{2}{|c|}{ Analisis Fatik } & \multicolumn{2}{|c|}{ Analisis Erosi } \\
\hline & & & & 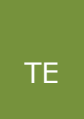 & ErosI & FRT & $\begin{array}{l}\text { Repetisi } \\
\text { Izin }\end{array}$ & $\begin{array}{c}\text { Persen } \\
\text { Rusak } \\
(\%)\end{array}$ & $\begin{array}{l}\text { Repetisi } \\
\text { Izin }\end{array}$ & $\begin{array}{c}\text { Persen } \\
\text { Rusak } \\
(\%)\end{array}$ \\
\hline$(1)$ & $(2)$ & (3) & $(4)$ & (5) & (6) & (7) & (8) & $(9)$ & (10) & $(11)$ \\
\hline \multirow[t]{4}{*}{ STRT } & $5(50)$ & 25 & $1.201 .242,67$ & \multirow{4}{*}{1,04} & \multirow{4}{*}{1,52} & \multirow{4}{*}{0,26} & $\pi$ & 0 & $\pi$ & 0 \\
\hline & $4(40)$ & 20 & $3.822 .135,75$ & & & & $\pi$ & 0 & $\pi$ & 0 \\
\hline & $3(30)$ & 15 & $2.074 .873,70$ & & & & $\pi$ & 0 & तT & 0 \\
\hline & $2(20)$ & 10 & $3.822 .135,75$ & & & & ता & 0 & $\pi$ & 0 \\
\hline \multirow[t]{3}{*}{ STRG } & $8(80)$ & 20 & $1.228 .359,65$ & \multirow{2}{*}{1,93} & \multirow{2}{*}{2,52} & \multirow{2}{*}{0,48} & 6.000 .000 & 20,47 & $\pi$ & 0 \\
\hline & $5(50)$ & 12.5 & $2.004 .165,74$ & & & & $\pi$ & 0 & Tा & 0 \\
\hline & & & Total & & & & $20,47<$ & $100 \%$ & $12,28<$ & $100 \%$ \\
\hline
\end{tabular}

Sumber: Analisis Data, 2020

Hasil analisis dengan ketebalan taksiran $170 \mathrm{~mm}$, menunjukkan hasil yang memadai untuk menampung beban rencana. MDPJ 2017 (Direktorat Jenderal Bina Marga, 2017), merekomendasikan tebal pelat beton perkerasan kaku dengan beban lalu lintas rendah, tanpa bahu pelat beton (tied shoulder), menggunakan lapis pondasi drainase Agregat kelas A tebal $150 \mathrm{~mm}$, dan dapat diakses oleh truk, dengan ketebalan sebesar $180 \mathrm{~mm}$. Data awal LHR menampilkan adanya komposisi kendaraan micro truck (6.2) dan truck 2 sumbu-sedang (7.2), sehingga tebal pelat beton rencana digunakan ketebalan $180 \mathrm{~mm}$.

\section{b. Metode AASHTO 1993}

Desain tebal perkerasan kaku menggunakan metode AASHTO 1993 ini dimulai dengan menghitung volume lalu lintas rancangan $\left(\mathrm{W}_{18}\right)$ pada akhir umur rencana sesuai Persamaan (4), selanjutnya ditetapkan nilai parameter reliability $(R)$, deviasi standar normal $\left(Z_{R}\right)$, standar deviasi keseluruhan $\left(S_{0}\right)$, analisis kehilangan kemampuan 
JURNAL BORNEO SAINTEK

Volume 3, Nomor 2, Oktober 2020

e-ISSN 2599-3313

P-ISSN 2615-434X

pelayanan ( $\triangle \mathrm{PSI}$ ), analisis nilai $\mathrm{k}$, hingga diperoleh tebal pelat beton rencana. Analisis lalulintas rancangan menggunakan data dan parameter sama dengan yang digunakan pada metode
Available online at www.jurnal.borneo.ac.id Halaman 47-60

Tabel 11. Analisis Equivalent Single Axle Load (ESAL)

\begin{tabular}{|c|c|c|c|c|c|c|}
\hline Jenis Kendaraan & $\operatorname{LHR}_{(2022-2042)}$ & VDF & $\begin{array}{l}\operatorname{LHR}_{(2022-2042) X} \\
\text { VDF } \\
\end{array}$ & DD & DL & $W_{18}$ \\
\hline$(1)$ & (2) & (3) & $(4)$ & (5) & $(6)$ & (7) \\
\hline Minibus (5a) & 10.112 & 0.3 & 3.034 & 0.5 & 1 & 553.651 \\
\hline Micro truck (6.2) & 19.390 & 0.8 & 15.512 & 0.5 & 1 & 2.830 .942 \\
\hline Truck 2 sumbu-sedang (7.2) & 6.196 & 1.6 & 9.913 & 0.5 & 1 & 1.809 .178 \\
\hline Juml & alu Lintas pac & lajur & a $\left(W_{18}\right)$ & & & 5.193 .771 \\
\hline
\end{tabular}

Sumber: Analisis Data, 2020

MDPJ 2017 menghasilkan nilai Equivalent Single Axle Load (ESAL) yang digunakan dalam tahapan desain berikutnya. Proses analisis ESAL sebagaimana disajikan pada Tabel 11.

Keterangan: $(2)=$ Data LHR Tahun 2022 pada Tabel $4 \times\left(\mathrm{R}_{(2022-2042)}=\left[(1+0,01 \times 5,5)^{19}\right.\right.$ 1) $/(0,01 \times 5,5)]=32) ;(4)=(2) \times(3) ;(7)=(4) \times(5) \times(6) \times 365$

Selanjutnya, dengan nilai traffic design $\left(W_{18}\right)$ yang diperoleh menjadi salah satu parameter analisis tebal pelat beton perkerasan kaku, bersama parameter lainnya seperti disajikan pada Tabel 12 .

\section{Tabel 12. Parameter Analisis Tebal Pelat Beton Perkerasan Kaku}

\begin{tabular}{|c|c|c|}
\hline Parameter & $\begin{array}{l}\text { Nilai parameter } \\
\text { desain }\end{array}$ & Keterangan \\
\hline Umur rencana & 20 tahun & $\begin{array}{l}\text { Umumnya uur rencana perkerasan kaku ditetapkan } 40 \\
\text { tahun, namun dalam studi dipergunakan umur rencana } 20 \\
\text { tahun }\end{array}$ \\
\hline Beban Ialu lintas, ESAL (W18) & 5.193 .771 & Hasil analisis ESAL seperti disajikan pada Tabel 11 \\
\hline Terminal serviceability (Pt) & 2,0 & $\begin{array}{l}2,0-3,0 \text { (nilai Pt }=2,0 \text { untuk jalan lalu lintas rendah, } \mathrm{Pt}= \\
2,5 \text { untuk jalan utama (major highway), diambil dari } \\
\text { AASHTO } 1993 \text { hal. II-10) }\end{array}$ \\
\hline Initial serviceability (Po) & 4,5 & $\begin{array}{l}\text { 4,5 (nilai pelayanan awal, diambil dari AASHTO } 1993 \text { hal. } \\
\text { II-10) }\end{array}$ \\
\hline Serviceability loss ( $\triangle \mathrm{PSI})$ & 2,5 & Total loss of serviceability $\left(\triangle \mathrm{PSI}=\mathrm{P}_{\mathrm{o}}-\mathrm{P}_{\mathrm{t}}\right)$ \\
\hline Reliability (R) & $80 \%$ & $\begin{array}{l}75 \%-99,9 \% \text { (diambil dari AASHTO } 1993 \text { hal. II-9, nilai R } \\
\text { untuk jalan lokal luar kota berada pada nilai: } 50-80 \text { ) }\end{array}$ \\
\hline Standar deviasi normal $\left(Z_{R}\right)$ & $-0,841$ & $\begin{array}{l}-0,674 \mathrm{~s} / \mathrm{d}-1,645 \text { (diambil dari AASHTO } 1993 \text { hal. I-62, } \\
\text { nilai } Z_{R} \text { berkorelasi dengan nilai R) }\end{array}$ \\
\hline $\begin{array}{l}\text { Standar deviasi keseluruhan } \\
\text { (So) }\end{array}$ & 0,37 & $\begin{array}{l}\text { 0,30 - 0,40 (diambil dari AASHTO } 1993 \text { hal. I-62, } \\
\text { disarankan nilai } 0,37 \text { atau 0,38) }\end{array}$ \\
\hline $\begin{array}{l}\text { Modulus reaksi tanah dasar } \\
\text { (k) }\end{array}$ & 160 & $\begin{array}{l}\text { Berdasar nilai CBR }=6 \% \text { (CV. Menara Konsultan, 2019), } \\
\text { menggunakan hubungan nilai CBR dengan k diambil dari } \\
\text { Buku Teknik Jalan Raya Edisi Kemepta Jilid } 2 \text { (terjemahan) } \\
\text { (Oglesby dan Hicks, 1982) }\end{array}$ \\
\hline Modulus elasisitas beton (Ec) & $3.723 .326,21 \mathrm{psi}$ & $\begin{array}{l}\text { Berdasar: } \mathrm{f}^{\prime} \mathrm{c}=300 \mathrm{~kg} / \mathrm{cm} 2(4.267 \mathrm{psi}) \text {, dihitung dengan } \\
\text { formula } \mathrm{Ec}=57.000 \mathrm{Jf} \mathrm{f}^{\prime} \mathrm{c}\end{array}$ \\
\hline Kuat tarik lentur $(\mathrm{Sc})$ & $640 \mathrm{psi}$ & Berdasar: $\mathrm{S}^{\prime} \mathrm{c}=45 \mathrm{~kg} / \mathrm{cm} 2$ \\
\hline Koefisien dranase $(\mathrm{Cd})$ & 1,10 & 0,70 - 1,25 (diambil dari AASHTO 1993 hal II-26) \\
\hline Koefisien transfer beban $(\mathrm{J})$ & 2.7 & $2,50-3,10$ (diambil dari AASHTO 1992 hal II-26) \\
\hline
\end{tabular}

Sumber: Analisis Data, 2020

Dengan menggunakan data-data pada Tabel 12, yang disubtitusikan kedalam Persamaan (5), kemudian dianalisis secara trial and error untuk mendapatkan tebal perkerasan rencana sebesar 6,60 inchi atau 167,64 mm, dibulatkan menjadi $170 \mathrm{~mm}$. Lapis pondasi direncanakan menggunakan beton kurus (Lean Mix Concrete, LMC) setebal 100 $\mathrm{mm}$ dan mutu beton $\mathrm{f}^{\prime} \mathrm{c} 10 \mathrm{MPa}$, serta 
JURNAL BORNEO SAINTEK

Volume 3, Nomor 2, Oktober 2020

e-ISSN 2599-3313

P-ISSN 2615-434X

lapis pondasi drainase agregat kelas A setebal $150 \mathrm{~mm}$.

\section{c. Komparasi Hasil Analisis Metode MDPJ 2017 dengan Metode AASHTO 1993}

Hasil desain menggunakan metode MDPJ 2017 mendapatkan tebal pelat beton sebesar $170 \mathrm{~mm}$, dan kemudian disesuaikan menjadi $180 \mathrm{~mm}$, sedangkan hasil desain dengan menggunakan metode AASHTO 1993 diperoleh tebal pelat sebesar $167,64 \mathrm{~mm}$, dan dibulatkan menjadi $170 \mathrm{~mm}$. Terdapat selisih tebal pelat sebelum dibulatkan sebesar 2,36 $\mathrm{mm}$ atau sebesar $1,4 \%$. Perbedaan hasil analisis kedua metode ini relatif kecil, meskipun parameter yang digunakan kedua metode terdapat beberapa perbedaan, seperti penentuan tebal pelat beton. Pada metode MDPJ 2017, menggunakan dimensi yang telah ditetapkan secara tabelaris dengan nilai bulat dan rentang ketebalan $150 \mathrm{~mm}$ hingga $350 \mathrm{~mm}$, dengan variasi ketebalan bertambah $10 \mathrm{~mm}$ setiap tingkatan ketebalan taksiran. Pada metode AASHTO 1993, ketebalan tidak diberikan rentang tetapi diperoleh dengan cara trial and error kedalam persamaan hingga mencapai keseimbangan, sehingga dimungkinkan memperoleh besaran tebal pelat yang tidak bulat.

\section{KESIMPULAN}

Berdasarkah analisis yang telah dilakukan dapat dibuat kesimpulan sebagai berikut:

1. Tebal pelat beton perkerasan kaku hasil analisis dengan metode MDPJ 2017, diperoleh setebal $170 \mathrm{~mm}$, dan kemudian dibulatkan menjadi 180 $\mathrm{mm}$, mengacu pada kriteria beban lalu lintas rendah, tanpa bahu pelat beton (tied shoulder), dan dapat diakses oleh truk ((Direktorat Jenderal Bina Marga, 2017). Tebal pelat beton hasil analisis dengan metode AASHTO 1993 diperoleh dengan ketebaln sebesar $167,64 \mathrm{~mm}$, dan dibulatkan menjadi $170 \mathrm{~mm}$.

2. Masing-masing didesain menggunakan lapis pondasi beton kurus (Lean Mix Concrete, LMC)
Available online at www.jurnal.borneo.ac.id Halaman 47-60

setebal $100 \mathrm{~mm}$ dan mutu beton $\mathrm{f}^{\prime} \mathrm{c} 10$ $\mathrm{MPa}$, serta lapis pondasi drainase agregat kelas A setebal $150 \mathrm{~mm}$.

3. Perbedaan hasil pada kedua metode relatif kecil $(1,4 \%)$, meskipun terdapat perbedaan beberapa parameter, tetapi tidak berpengaruh secara signifikan.

\section{DAFTAR PUSTAKA}

AASHTO. (1993). AASHTO Guide for Design of Pavement Structures 1993. Washington, D.C: American Association of State Hihway and Transportation Officials.

Ardiansyah, R., \& Sudibyo, T. (2020). Analisis Perencanaan Tebal Perkerasan Kaku Lajur Pengganti pada Proyek Pembangunan Jalan Tol Jakarta-Cikampek II Elevated. Jurnal Teknik Sipil Dan Lingkungan, 5(1), 17-30. https://doi.org/10.29244/ jsil.5.1.17-30

Bakri, M. D. (2020). Analisis Tebal Perkerasan Lentur Menggunakan Metode AASHTO 1993 (Studi Kasus pada Pembangunan Jalan Lingkungan Baru Dalam Kawasan Kampus Universitas Borneo Tarakan). Jurnal Teknik Sipil, Borneo Engineering, 4(1), 30-44.

CV. Menara Konsultan. (2019). Laporan Hasil Perencanaan Jalan Lingkungan Dalam Kawasan Kampus Universitas Borneo Tarakan Tahun 2019 (p. 90). p. 90. Tarakan: Bagian Perencanaan BPK2U Universitas Borneo Tarakan.

Departemen Permukiman dan Prasarana Wilayah. (2003). Perencanaan Perkerasan Jalan Beton Semen (Pd T-14-2003) (p. 51). p. 51. Jakarta: Departemen Permukiman dan Prasarana Wilayah Republik Indonesia.

Departemen Permukiman dan Prasarana Wilayah. (2004). Pedoman Survei Pencacahan Lalu Lintas dengan Cara Manual (Pd T-19-2004-B) (p. 36). p. 36. Jakarta: Departemen Permukiman dan Prasarana Wilayah Republik Indoensia.

Direktorat Jenderal Bina Marga, K. 
JURNAL BORNEO SAINTEK

Volume 3, Nomor 2, Oktober 2020

e-ISSN 2599-3313

P-ISSN 2615-434X

(2017). Manual Desain Perkerasan Jalan (Revisi 2017) Nomor. 02/M/BM/2017. Jakarta: Direktorat Jenderal Bina Marga Kemen PUPERA.

Dumin, L., Liem, F. N., \& Maridi, A. S. S. (2017). Komparasi Hasil Perencanaan Rigid Pavement Menggunakan Metode AASHTO '93 Dan Metode Pd T-14-2003 Pada Ruas Jalan W. J. Lalamentik Kota Kupang. JUTEKS (Jurnal Teknik Sipil), 2(2), 124-128. https://doi.org/DOI prefix: 10.32511

Hendarsin, S. L. T. (2000). Penuntun Praktis Perencanaan Teknik Jalan Raya (Pertama). Bandung: Politeknik Negeri Bandung-Jurusan Teknik Sipil.

Irawan, S. R., Subagio, B. S., Hariyadi, E. S., \& Gerardo, F. (2017). Evaluasi Struktural Perkerasan Kaku Menggunakan Metoda AASHTO 1993 dan Metoda AUSTROADS 2011 Studi Kasus: Jalan Cakung-Cilincing. Jurnal Teknik Sipil ITB, 24(2), 173182.

https://doi.org/10.5614/jts.2017.24 .2 .9

Isnaini, A. Y., Suparma, L. B., \& Utomo, S. H. T. (2019). Perancangan Perkerasan Jalan Lingkar Kota Kabupaten Wonogiri. Jurnal HPJI, 5(2), 119-128. https://doi.org/ 10.26593/jh.v5i2.3372.119-128

Kurniawan, A., Winarto, S., \& Cahyo SP, Y. (2019). Studi Perencanaan Peningkatan Jalan Pada Ruas Jalan Jalur Lintas Selatan Giriwoyo-Duwet STA. $10+000$ - STA. $15+000$. JURMATEKS, 2(1), 39-50. Retrieved from http://dx.doi.org/10.30737/ jurmateks.v2i1.390

Nawir, D., \& Mansur, A. Z. (2017).
Available online at www.jurnal.borneo.ac.id Halaman 47-60

$\begin{array}{lll}\text { Rancangan } & \text { Perkerasan } & \text { Jalan } \\ \text { (Pertama). } & \text { Makassar: } & \text { Rinra } \\ \text { Publishing. } & & \end{array}$

Oglesby, C. H., \& Hicks, R. G. (1982). Teknik Jalan Raya (terjemahan) (Keempat Ji; P. W. Indarto, Ed.). Jakarta: Erlangga.

Putranto, Y. P., Ridwanyah, A. M., Djakfar, L., \& K, R. (2016). Perencanaan Tebal Perkerasan Kaku (Rigid Pavement) Pada Ruas Jalan Tol Karanganyar - Solo. Jurnal Mahasiswa Jurusan Teknik Sipil Universitas Brawiya, 2(1), 504-523. Retrieved from http://sipil.studentjournal.ub.ac.id/i ndex.php/jmts/issue/view/12

Setiawan, A. B. (2017). Perencanaan Tebal Perkerasan Kaku (Rigid Pavement) Dengan Menggunakan Metode AASHTO 1993 Dan Metode Bina Marga Pada Bahu Jalan Tol Gempol Â- Pasuruan Seksi A1 (STA 0+000 Â- STA 6+800) (Universitas Muhammadiyah Malang). Retrieved from http://eprints.umm.ac.id/id/ eprint $/ 35390$

Siegfried, S., \& Rosyidi, S. A. P. (2007). Deskripsi Perencanaan Tebal Perkerasan Jalan Menggunakan Metode AASHTO 1993 (p. 6). p. 6. Retrieved from https://labtransportumy.files.wordp ress.com/2007/11/webpublishnarasi-\%0Aaashto93.pdf

Vinna, A. D., Prihutomo, N. B., \& Pramono, E. (2019). Analisis Tebal Perkerasan Kaku Metode AASHTO 1993 dan Metode Bina Marga 2017 Serta Biaya Pelaksanaan (Studi Kasus Proyek Jalan Tol CinereSerpong Seksi 1). Seminar Nasional Teknik Sipil Politeknik Negeri Jakarta, 496-506. Jakarta. 